\title{
OS SENTIDOS DA SOCIOLOGIA ESCOLAR NOS LIVROS DIDÁTICOS NO BRASIL
}

\section{THE MEANINGS OF SCHOOL SOCIOLOGY IN TEXTBOOKS IN BRAZIL}

\author{
Ana Martina Baron Engerroff* \\ Amurabi Oliveira**
}

\section{Introdução}

A pesquisa sobre o ensino de sociologia vem apresentando um incremento contínuo, especialmente a partir do processo de reintrodução da sociologia no currículo escolar em 2008, como bem apontam os inúmeros balanços recentes (BODART, CIGALES, 2017; HANDFAS, 2017). Destaca-se que esse período também coincide com um momento de expansão do ensino superior, considerando tanto a graduação quanto a pós-graduação, o que em parte nos ajuda a compreender o crescimento exponencial de dissertações e teses sobre o tema.

É nesse cenário de expansão, que a temática sobre o livro didático de sociologia vem ganhando espaço, ainda que Muna- kata (2001, p. 337) tenha observado que, apesar das várias dimensões (educacional, cultural e mercantil) do livro didático, este objeto, no geral, não guardava muita atenção como o tema de investigação universitária no contexto brasileiro. Faltariam, então, estudos que compreendessem que este tipo de texto está incluído em um contexto de produção de bens culturais e de todo o processo histórico que isso implica.

A dispersão dos estudos sobre os livros didáticos pode ser lida pela perspectiva da contradição que o próprio objeto guarda. Ao mesmo tempo em que o Brasil é um dos países do mundo com maior volume de vendas de livros didáticos, como observam Cassiano (2005) e Munakata (2001) ${ }^{1}$, este material por si goza de pouco prestígio so-

\footnotetext{
* Doutoranda e Mestra em Sociologia Política pela Universidade Federal de Santa Catarina (Florianópolis/ SC/BR). Bolsista CAPES. E-mail: anambaron@hotmail.com

** Doutor em Sociologia pela Universidade Federal de Pernambuco (UFPE), professor da Universidade Federal de Santa Catarina - UFSC (Florianópolis/SC/BR). Pesquisador do CNPq. E-mail: amurabi_cs@hotmail.com 1. Apenas entre 1995-1996 mais de 50\% dos livros produzidos e vendidos no Brasil correspondiam a livros didáticos, segundo Munakata (2001).
} 
cial, dando-se pouca atenção tanto na área da educação, quanto na área da sociologia e da história do livro brasileiro, como afirma Batista (1999).

Situando as pesquisas sobre o livro didático de sociologia, no artigo de Handfas e Maçaira (2014), as autoras já apontavam para a existência de trabalhos nesta temática, entre os quais destacamos o de Meucci (2000), a respeito dos manuais da década de 1920 e 1930, e o Sarandy (2004), que aborda os manuais a partir da década de $1980^{2}$. Atualizando o estudo, Handfas (2017) indica o aumento de trabalhos envolvendo livros didáticos no âmbito das pós-graduações, mapeamento também explorado recentemente por Engerroff (2017), confirmando o incremento no interesse sobre este objeto e a importância que ele parece possuir na consolidação da área do ensino de sociologia.

Por isso, entendemos que o livro didático tem se tornado cada vez mais fortemente um capital cultural (BOURDIEU, 2015) decisivo para a legitimidade do ensino de sociologia, enquanto campo acadêmico. É importante ressaltar que a produção e a circulação de livros escolares não é recente, participando dos processos de rotinização ${ }^{3}$ da sociologia no Brasil. Fato é que os manuais para o ensino de sociologia no Brasil já se viam presentes desde a década de 20 do século passado, transpassando também períodos em que a disciplina não figurava como obrigatória no currículo nacional ${ }^{4}$.

Na visão de Meucci (2014), o campo da sociologia do conhecimento não valorizaria o livro didático porque são consideradas obras menores, dedicadas à síntese escolar. Em oposição, para a autora os livros didáticos são "recursos valiosos para a compreensão da dinâmica de constituição de um repertório estável de conceitos, autores, temas e problemas de determinada disciplina entre membros da sociedade em geral" (MEUCCI, 2014, p. 211).

Notadamente, com a introdução da sociologia no Programa Nacional do Livro Didático (PNLD) em 2012, observou-se um crescente interesse por esse objeto de pesquisa, ao mesmo tempo em que se ampliou o próprio mercado editorial nesta seara. Nas três edições do programa, nas quais a sociologia participou, houve a aprovação de dois livros (2012), seis livros (2015) e cinco livros (2018), de modo que se pode inferir através destes dados que houve uma melhoria qualitativa na produção dos livros didáticos de sociologia a partir do segundo edital ${ }^{5}$.

Considerando tais aspectos, o presente trabalho visa analisar os sentidos que são atribuídos à sociologia nos livros didáti-

2. Além de Meucci (2000) e Sarandy (2004), foram localizados: COAN, M. A sociologia no ensino médio, o material didático e a categoria trabalho. 2006. 356 f. Dissertação (Mestrado em Educação) - UFSC, 2006; TAKAGI, C. Ensinar sociologia: análise de recursos do ensino na escola média. 2007. 277 f. Dissertação (Mestrado em Educação) - FFLCH/, USP, São Paulo, 2007; e PERUCCHI, L. Saberes sociológicos nas escolas de nivel médio sob a ditadura militar: os livros didáticos de OSPB. 2009. Dissertação (Mestrado em Educação) - UFSC, Florianópolis, 2009

3. Termo utilizado por Simone Meucci, tendo por base a ideia de rotinização do carisma em Max Weber.

4. Já há pesquisas em andamento que se debruçam sobre a concepção mais ampla de livro didático, integrando apostilas e fascículos, o que foi apresentado nos eventos mais recentes do Encontro Nacional de Ensino de Sociologia na Educação Básica (ENESEB) e do Congresso Brasileiro de Sociologia (SBS).

5. Esclarece-se no último edital do PNLD (2018), os cinco títulos aprovados correspondem aos mesmos aprovados no edital anterior e analisados neste artigo, com exceção do livro de Nelson Dácio Tomazi. 
cos aprovados no PNLD 2015. Em nossa compreensão, esses sentidos entrelaçam-se, sobretudo com a percepção de sociologia produzida no Brasil, mais especificamente nas concepções de ciência sociológica que vêm circulando nos espaços escolares em período recente. Trata-se, portanto, de uma análise sociológica da sociologia, a partir da realidade escolar e através de objetos que estão intimamente ligados à própria trajetória deste campo.

Para uma melhor compreensão por parte do leitor das questões que são aqui trazidas, primeiramente realizaremos uma breve exposição dos procedimentos metodológicos adotados, para em seguida apresentar as concepções de sociologia presentes nestes livros, o que será realizado separadamente a partir de cada obra. Por fim, já nas considerações finais, buscaremos realizar um balanço mais amplo em termos comparativos, para desse modo captar se há um sentido para o ensino de sociologia no Brasil.

\section{0 livro didático de sociologia e suas con- cepções de sociologia}

\subsection{Procedimentos metodológicos para a análise do livro didático de sociologia}

A autoria dos livros didáticos é marcador importante na concepção da sociologia escolar, uma vez que os autores e as autoras dos livros didáticos possuem uma trajetória que explicita a sua participação no campo científico e educacional, possibilitando apreender a sua posição nesse espaço social. 0 enfoque dado nesta seção é inferir se os autores e as autoras dos livros didáticos são agentes ativos no subcampo do ensino de sociologia ${ }^{6}$ e qual a sua aproximação com esta área.

Há pistas desta relação entre o campo educacional e o sociológico, uma vez que o próprio guia do PNLD (BRASIL, 2014) aponta para a diversidade de autoria dos livros didáticos, sendo professores de nível básico e também de nível superior, o que é visto como "uma tendência interessante de encorajamento de intelectuais dos dois níveis de ensino na produção de livros didáticos, fortalecendo a sociologia como conhecimento escolar” (BRASIL, 2014, p. 11). Por outro lado, carece um trabalho que sistematize a formação dos autores.

A análise da autoria percorreu cada um dos autores e das autoras dos livros didáticos aprovados no PNLD 2015. Isto porque se torna necessário contextualizar os autores com a obra, possibilitando verificar como eles constroem o sentido de sociologia através da sua relação com o subcampo do ensino de sociologia.

Dessa forma, para a configuração da autoria, tomaram-se os dados disponíveis na Plataforma Lattes $^{7}$, organizando a análise em cinco eixos: I. Graduação; II. Pós-Graduação; III. Docência; IV. Produção na área

6. Corroborando com Ferreira, Oliveira (2015) e na perspectiva teórica bourdieusiana, toma-se o espaço social do ensino de sociologia como um subcampo do campo sociológico, uma vez que, devido à sua persistente marginalidade, ainda não conseguiu estabelecer sua autoridade científica necessária para a maior autonomização.

7. A plataforma Lattes é uma base de dados vinculada ao CNPq, que integra currículos, grupos de pesquisa e instituições. Nesta plataforma é possível consulta o currículo Lattes, que se tornou o padrão nacional de registro de vida pregressa e atual dos estudantes e pesquisadores do país, constando o inventário de atividades desenvolvidas, formação, áreas de interesse, produção técnica, dentre outros. É uma base alimentada por cada pesquisador/estudante. 
do ensino de sociologia; e V. Atualização do Currículo Lattes. Para os três primeiros eixos, foi levada em consideração a data de corte sendo dezembro de 2014, uma vez que é o ano em que o edital do PNLD 2015 foi finalizado percebendo-se a relação dos agentes produtores do livro didático com o campo científico a tempo dos editais. Nos eixos posteriores, tomou-se toda a extensão do currículo (até a data atual), uma vez que demonstra como os autores relacionam-se com a produção acadêmica sobre o ensino de sociologia em toda a sua trajetória. Esclarece-se, ainda, que algumas informações foram complementadas com outros materiais, como no caso de entrevista de Nelson Tomazi (PEREIRA, 2017).

Para a análise dos seis livros didáticos, primeiramente foram destacadas as propriedades que foram recorrentes nas narrativas acerca da intermitência da sociologia como disciplina escolar e dos objetivos do ensino de sociologia contidos nos currículos. Desta maneira, destacaram-se os seguintes elementos: disciplina de sociologia; senso comum; ferramenta de análise; imaginação sociológica; desnaturalização; estranhamento; crítica social; intervenção social; formação para a cidadania; formação para transformação social; outros. Deve-se esclarecer que os livros didáticos foram analisados na integralidade dos textos, inclusive nas atividades sugeridas, uma vez que elas assumem um caráter mais propositivo do objetivo final da sociologia escolar.

Assim, nas subseções a seguir são apresentadas interlocuções entre autoria e análise textual dos livros didáticos. Quer-se, sobretudo, evitar uma análise substancialis- ta destes objetos, nos termos de uma sociologia relacional de Bourdieu (2012), compreendendo que os agentes e as obras estão imbricados em contextos mais amplos, na interlocução com os diferentes campos e, mais especificamente, com o subcampo do ensino de sociologia. Além disso, conforme aponta Choppin (2004), deve-se ultrapassar a análise de conteúdo dos livros didáticos, enfrentando-os em seus diversos elementos e contextos.

\subsection{Sociologia para o ensino médio - TO- MAZI, 2015}

Nelson Dácio Tomazi é talvez o autor de livros didáticos mais conhecido no âmbito da sociologia. Através do título Sociologia para o ensino médio participou de todos os editais do PNLD de sociologia ${ }^{8}$, possuindo também outras obras didáticas, que chegaram a influenciar os documentos oficiais, conforme indica Maçaira (2017). 0 livro Iniciação à Sociologia, finalizado em 1993, constou nas referências bibliográficas do $\mathrm{PNC}+$, e foi a primeira experiência de Tomazi na elaboração de materiais didáticos, realizando um projeto em conjunto com outros professores universitários, "com pouca experiência em ensino médio” (PEREIRA, 2017, p. 231). Por isso, afirma Tomazi, o livro serviria muito mais aos professores do ensino médio do que aos alunos, tendo uma linguagem "muito acadêmica" (PEREIRA, 2017, p. 231).

0 título Sociologia para o ensino médio, por sua vez, seria mais voltado para os alunos dessa etapa escolar e é fruto, na leitura do autor (PEREIRA, 2017), da sua trajetória de aproximação com o ensino de so- 
ciologia $^{9}$. Esta aproximação, porém, se deu por meio do ensino superior, uma vez que Tomazi, embora licenciado em ciências sociais pela Universidade Federal do Paraná (UFPR), não exerceu a docência no ensino básico, enfocando sua carreira de professor e pesquisador no âmbito do ensino superior, na Universidade Estadual de Londrina $(\mathrm{UEL})^{10}$. Foi por meio dos livros didáticos que autor passou a se envolver com o subcampo em formação, tanto ministrando cursos e disciplinas, quanto participando de eventos e da elaboração de documentos curriculares, dentre eles, as Orientações Curriculares Nacionais para o Ensino Médio (OCNEM) ${ }^{11}$.

A atuação na UEL não parece ser um mero acaso, uma vez que esta é uma destacada instituição no debate sobre ensino de sociologia. Mais que isso, no próprio estado do Paraná a sociologia foi sendo paulatinamente introduzida nos currículos escolares desde os anos de 1990, o que pode apontar para o fato de que em sua trajetória como professor e pesquisador, Tomazi, possivelmente, deve ter tido contato com as demandas dos professores de sociologia da educação básica acerca da necessidade de produção de material didático.

Assim, no PNLD 2015 este livro foi aprovado já na sua $3^{a}$ edição, contemplando, segundo o guia PNLD 2015 (BRASIL, 2014), uma visão histórica de tratamento dos temas. Esta perspectiva parece estar influenciada pela formação do autor, que na sua pós-graduação em história (pela UFPR) dedicou-se à preocupação de auxiliar aqueles que lecionam sociologia, sendo formados em história, conforme constou em Pereira (2017) ${ }^{12}$. Nesta perspectiva, o livro está organizado de modo a contemplar, como elemento à parte, a apresentação da sociologia ao aluno na "Introdução", incluindo um apêndice dedicado à "História da Sociologia: pressupostos, origem e desenvolvimento". De fato, a frente histórica é o eixo condutor do livro e partir dela é que se desenvolvem a apresentação, os temas e os conteúdos.

Tomazi (2013) estrutura o livro em sete unidades, com as principais temáticas que serão trabalhadas em cada capítulo. São elas: 1. A sociedade dos indivíduos; 2. Trabalho e sociedade; 3 . A estrutura social e as desigualdades; 4. Poder, política e Estado; 5. Direitos, cidadania e movimentos sociais; 6 . Cultura e ideologia; 7. Mudança social.

$\mathrm{Na}$ parte introdutória depreendem-se os objetivos da sociologia escolar apontados por Tomazi (2013). 0 ponto em destaque no livro é que a sociologia escolar se assenta pela cientificidade, no propósito de dotar o aluno do conhecimento científico. Tem-se a perspectiva de que é "possivel conhecer a sociedade por meio da ciência”, como é o caso da sociologia (p. 6). A sociologia permitiria entender as questões que envolvem o cotidiano dos indivíduos, dos grupos e da sociedade, fornecendo as ferramentas para uma análise consistente: "por meio da so-

9. A primeira edição data de 1997 e foi elaborada a pedido da então Editora Atual, hoje Saraiva. 0 primeiro livro também foi elaborado a convite da mesma editora, conforme consta em Pereira (2017).

10. Tomazi é professor aposentado pela UEL.

11. Além de outras produções no subcampo do ensino de sociologia, Tomazi também esteve presente no GT do Livro Didático no último ENESEB (2017).

12. É fato notório e já demonstrado nos censos escolares que a maior parte dos professores que lecionam sociologia no ensino médio não é formada na área, conforme se verifica em INEP (2017). 
ciologia, obtemos um conhecimento científico sobre a realidade social" (p. 7).

Esta forte relação entre o campo científico e o campo educacional é percebida pelo próprio autor, que já afırmou:

[...] Sociologia para o Ensino Médio, possui uma estrutura diferente e atende bem mais aos alunos deste nível, mas mesmo assim, penso que é um projeto que ainda tem por base uma visão acadêmica da sociologia para a escola média. É bom, porque introduz o aluno nos clássicos da sociologia e em alguns autores contemporâneos com temáticas bem tradicionais na literatura sociológica. É, pois, um manual que atende aos interesses dos professores licenciados em ciências sociais, que são minoria nas escolas. Atende também os professores licenciados em história, que ministram aulas de sociologia, pois tem uma forte fundamentação histórica em todos os temas [...] Além disso, penso que os alunos conseguem perceber que a sociologia lhes permite ver o mundo com outros olhos, menos ingênuos, e que lhes dá algumas ferramentas para pensar o seu cotidiano e entender algumas coisas além do senso comum. (TOMAZI, 2017, p. 232)

É, portanto, por meio da reafirmação da sociologia enquanto campo científico que o livro de Tomazi (2013) é guiado. 0 que tornaria a sociologia uma disciplina propriamente dita é a sua capacidade de ultrapassar o senso comum, elaborando conceitos e teorias. Especificamente no Brasil, Tomazi afırma que a sociologia se tornou mais visível pela presença dos institutos de pesquisa social e dos cursos de graduação e pós-graduação, além da atuação dos sociólogos em muitos órgãos públicos e privados, e nos meios de comunicação de massa. A visão da sociologia enquanto ciência é reforçada nas atividades, para caracterizar o "modo científico de pensar", o que demonstra o enredamento do autor com os processos de afırmação da sociologia como uma disciplina escolar.

Propriedades da sociologia, tais como imaginação sociológica, crítica social, transformação social e pesquisa sociológica, são consequências do pensar cientificamente a sociologia. Porém, esta sociologia científica, enquanto campo científico e subsequentemente o ensino de sociologia, guarda um sentido iminentemente crítico e transformador da sociedade.

A função da sociologia é contribuir para "desenvolver nossa imaginação sociológica” (TOMAZI, 2013, p. 7), tida como a capacidade de analisar as experiências e perceber as relações entre elas e outras condições mais amplas, explicando o que acontece na nossa vida. Isto posto, a sociologia revelaria aspectos da sociedade que pode, por uma postura crítica, incomodar muitos grupos e indivíduos. É por esse motivo, também, que a sociologia incomoda, por poder fazer questionamentos e provocar ressentimentos nos que estão estabelecidos (p. 11). 0 "pensar sociologicamente" é se tornar mais tolerante e sensível à diversidade e aberto a novas possibilidades. A sociologia está aqui apresentada como crítica social.

Portanto, a questão da crítica social parte, no livro de Tomazi (2013), de uma questão intrínseca à sociologia enquanto ciência. A categoria cidadania faz parte da crítica, mas como uma temática afeita às ciências sociais, tida como conhecimento que questiona "quais [são os] nossos direitos e o que significa cidadania”? (p. 7).

Há uma unidade dedicada a pensar a cidadania na sua relação com os direitos e com os movimentos sociais (Unidade 5), 
questionando se, em uma sociedade desigual como a brasileira, os direitos são de fato para todos. A crítica social decorre desta constatação da desigualdade social, o que leva à ideia desejada de transformação social, evocada na Unidade 7 "Mudança Social". No entanto, esta mudança não se dá por uma ideia de prática cidadã por parte do aluno, mas como algo que decorre da própria sociologia em suas análises e como um efeito da vida em sociedade.

A pesquisa é o elemento-chave colocado no livro para constituir a sociologia, apresentando algumas fontes utilizadas e temas eleitos por sociólogos para elaborar as suas pesquisas. Conclui-se que "aprender a pensar sociologicamente implica, assim, fazer pesquisas, mesmo que sejam pequenas. Por isso, ao longo desse livro vamos indicar temas diversos para pesquisas que poderão ser desenvolvidas com a ajuda do professor" (TOMAZI, 2013, p. 10). Assim, a questão da pesquisa ganha relevância nas atividades contidas no final de unidade, incluindo a opção denominada "Para pesquisar", onde verifica-se um quadro que contém propostas para que o aluno realize pesquisa através da coleta de dados de caráter mais exploratório, como no caso de entrevistas e pesquisas de opinião, ou ainda mais informativas, pela pesquisa em jornais, em revistas e na internet, como pode ser visto em Tomazi e também já analisado por Oliveira e Cigales (2015).

Portanto, o livro de Tomazi (2013) apresenta uma concepção de sociologia escolar como transposição do conhecimento sociológico acadêmico, visando dotar o aluno do saber científico. A sociologia é apresentada como parte das ciências humanas, em que se busca conhecer a sociedade pelo conhecimento científico - com métodos e teorias próprias -, afastando o senso comum e contribuindo para o desenvolvimento da imaginação sociológica - uma ciência que parte do princípio de questionar as relações sociais e as desigualdades, sendo iminentemente crítica e visando, por consequência, à mudança social.

\subsection{Tempos Modernos, Tempos de Sociolo- gia - BOMENY et al, 2013}

0 livro didático Tempos Modernos, Tempos de Sociologia participou do PNLD 2012, sendo ganhador do Prêmio Jabuti em $2011^{13}$. Sendo assim, quando participou do primeiro PNLD, já havia o reconhecimento da comunidade editorial e literária do diferencial desta obra ${ }^{14}$.

De fato, o livro de autoria de Bomeny et al. (2013) possui uma formulação bem diferente dos demais, conduzindo-se pelo roteiro do conhecido filme "Tempos Modernos", de Charles Chaplin (1936) e encadeando as suas cenas com as abordagens teóricas clássicas e contemporâneas da sociologia. Isto também foi anotado pelo guia do PNDL (2014, p. 23), descrevendo que este livro faz um diálogo entre os autores e a ideia de modernidade, nas suas contradições. Com base no filme, as autoras querem "pensar sociologicamente" (BOMENY, et al., 2013, p. 73) sobre vários temas afeitos às ciências sociais.

Perpassando os currículos das autoras e os dados constantes no próprio livro, ve-

13. 0 Prêmio Jabuti é uma premiação anual ligada à Câmara Brasileira do Livro, sendo considerada uma das mais importantes do Brasil. Possui diversas categorias, dentre elas a de livro didático.

14. Embora na primeira edição conste apenas duas autoras, em entrevista concedida em 2011 Bomeny (2011) cita as coautoras no projeto originário. 
rifica-se que ele é resultado de pesquisas desenvolvidas junto ao Centro de Pesquisa e Documentação Histórica Contemporânea do Brasil (CPDOC), ligado à Escola de Ciências Sociais da Fundação Getúlio Vargas (FGV), na cidade do Rio de Janeiro. Além disso, a FGV possui diversas atuações educacionais, entre elas um programa voltado ao ensino médio, envolvendo também o desenvolvimento deste livro ${ }^{15}$.

Assim, este livro didático está fortemente interseccionado com as atividades de pesquisa desenvolvidas pelas autoras, seja na proposição específica do livro ou nas áreas de interesse. À exceção de Helena Bomeny, que é graduada em ciências sociais pela Universidade Federal Fluminense e doutora em sociologia pelo Instituto Universitário de Pesquisa do Rio de Janeiro (IUPERJ), as demais coautoras possuem formação conjunta em história (na graduação ou na pós) e nas ciências sociais (ou em suas áreas específicas). Todavia, as pesquisas desenvolvidas pelas quatro autoras perpassam as ciências sociais, as artes e a história - elementos estes que estão imbricados no livro Tempos Modernos, Tempos de Sociologia.

As autoras atuam no campo acadêmico, sendo vinculadas às instituições públicas de ensino superior como pesquisadoras e professoras. A participação no subcampo do ensino de sociologia é ainda tímida, não tendo as autoras lecionado sociologia no ensino básico ${ }^{16}$. Somente Helena Bomeny e Raquel Emerique, que já vinham pesquisando educação, chegaram a produzir no subcampo do ensino de sociologia, inclusive participando de eventos na área. No caso de Bomeny, destaca-se o fato de ser bolsista de produtividade em pesquisa junto ao CNPq, e atuante no Programa de PósGraduação em ciências sociais da UERJ, o que demarca claramente sua posição de distinção no campo acadêmico brasileiro.

Voltando-nos à organização do livro didático, a proposta de Bomeny et al. (2013) parte, então, da apresentação histórica da sociologia. Os 22 capítulos são alocados em três grandes partes, denominadas "Saberes cruzados", "A sociologia vai ao cinema", e "A sociologia vem ao Brasil", havendo ainda um glossário de conceitos sociológicos ao final. A primeira parte dedica-se à apresentação da disciplina e ao roteiro de viagem, contendo capítulos que visam apresentar as primeiras noções das ciências sociais. No decorrer do texto, são relembrados os papéis da sociologia frente às questões sociais e aos temas aqui destacados.

Segundo Bomeny et al. (2013, p. 8), a sociologia para o ensino médio teria duas tarefas claras: "expor de forma viva e clara o que é a sociologia [e a segunda] e mais importante - é despertar seu [do aluno] interesse para esse campo do conhecimento". A linha condutora é que a "sociologia é uma disciplina intelectual que pretende produzir um conhecimento sistemático sobre as relações sociais" (p. 8).

$\mathrm{Na}$ trilha da cientificidade, apresenta-se a sociologia como um guia, um mapa, tido como um "campo do conhecimento que modifica a percepção que temos" sobre o mundo ao redor, como a ciência da sociedade. A sociologia forneceria as ferramentas e os caminhos (distintos, por vezes), para chegar às perguntas que mais inquietam ou im-

15. Originalmente, este livro didático participava da Coleção Aprender, da FGV, sendo publicado pela Editora do Brasil, que mantém parcerias com a fundação.

16. Raquel Emerique foi professora de história no ensino básico, sua área de formação. 
pressionam, como forma de compreender os problemas. Assim, as ferramentas seriam os métodos sociológicos, como as informações de dados e de fontes. Neste viés, o conceito de pesquisa é colhido neste livro didático como forma consultiva, em que os alunos buscam informações complementares sobre determinado tema através de revistas, jornais e internet (conforme se pode verificar às p.75, 195 e 313, além de outras).

A sociologia enquanto ciência é formulada dentro do contexto de modernidade, enlaçando-se na proposta geral do livro. Assim, “o fundamento da ciência moderna consiste na necessidade de observar os fatos e fenômenos e demonstrar as explicações propostas para eles" (BOMENY et al., 2013, p. 17). A sociologia surge na valorização da razão, dentro do contexto da Revolução Industrial e do Século das Luzes, apostando na capacidade dos homens em modificar a realidade - e não mais em uma lógica divina e do sagrado. Esta área estaria então, conforme Bomeny et al. intrinsicamente ligada à liberdade de pensamento, do exercício da razão e da controvérsia e, por isso também, há diversidade de possibilidades de compreensão do mesmo fenômeno.

Visando rebater críticas que a "sociologia trata do que tudo mundo sabe”, as autoras buscam conciliar o senso comum com o objeto de estudo da sociologia para compreender o que seria uma disciplina intelectual. Afırma-se que as noções do senso comum por vezes coincidem com questões também atinentes à sociologia, mas que são noções parciais da realidade e que fundamentam as ações e interações sociais. Assim, "a sociologia como disciplina se vale do senso comum na medida em que usa essas explicações que as pessoas dão para sua existência como objeto de estudo" (BOMENY, et al., 2013, p. 09).
Aliado a esta construção do que é a sociologia, as autoras mobilizam fortemente o conceito de imaginação sociológica. Destaca-se a primeira referência, a partir de trecho de W. Mills (BOMENY et al., 2013), tida como uma qualidade de espírito que permite desenvolver a razão e perceber com lucidez o que está ocorrendo no mundo e dentro de nós mesmos. Propondo o exercício de imaginação sociológica, as autoras destacam que o mundo social muda - e 'nós' também mudamos, porque fazemos parte dele -, obrigando a sociologia também a se modificar e a provocar novas questões e respostas aos problemas que são apresentados. Do mesmo modo, a imaginação sociológica auxilia a desfazer enganos, como pensar que é fácil entender o Brasil (BOMENY, et al., 2013).

A imaginação sociológica seria o cerne do "fazer sociologia", que na qualidade de ciência com métodos, teorias e conceitos, apresenta uma pluralidade de posicionamento, não possuindo uma única resposta para tudo:

\begin{abstract}
A sociologia trata do que já sabemos de uma forma que não havíamos pensado antes. Falar de sociologia é chamar a atenção para uma pluralidade de olhares, de contribuições e sugestões, às vezes contraditórias, outras vezes complementares. Estes olhares nos ajudam a desenhar mapas que nos orientamos, mas esses mapas nunca são completos, assim como a vida em sociedade nunca se esgota. (BOMENY, et al., 2013, p. 198)
\end{abstract}

Tratando da ciência política, Bomeny et al. (2013) a direciona como o saber relacionado ao poder que indivíduos ou grupos exercem sobre outros, trazendo conceitos que decorrem do exercício desse poder. Cabe à ciência política o "estudo do exercício do 
poder em suas variadas formas de manifestação e também em entender o movimento da sociedade para fazer valer sua vontade diante do Estado" (p. 55). A cidadania, neste contexto, é apresentada como um tema da ciência política, tida como conquista histórica da democracia, enfım, de direitos sociais, de direitos civis e de direitos políticos. A cidadania também é tratada no olhar voltado ao Brasil, discutindo-a como um conceito dentro da noção de direitos e de deveres, apontando como finalidade da sociologia: "pensar e agir sociologicamente significa conectarmos com o que foi modificado e com o que ainda precisa ser aperfeiçoado. Esses são os desafios de nossa profissão e de nossa vida como detentores de direitos e deveres" (p. 310).

Do excerto, acima citado, colhe-se a noção de atuação de "práticas cidadãs", com o objetivo da sociologia em formar o aluno para a transformação social. 0 mesmo é percebido em algumas das atividades sugeridas, geralmente relacionadas ao quadro "exercitando a imaginação sociológica", como é o caso do exercício envolvendo "Cidadania e participação social” (BOMENY, et al., 2013, p. 317), em que se espera que o aluno "elabore uma proposta de ação social”. No entanto, estes quadros, como já afirmado anteriormente, são extraídos de propostas de redação de concursos (vestibulares, ENEM), replicando-as no livro didático e corroborando a sua intenção pelas demais assertivas contidas no livro.

Assim, pode-se extrair o entendimento que a finalidade da sociologia é agir em sociedade, por sermos também cidadãos (um dever-ser). Na mesma vertente, colocam Bomeny et. al. (2013, p. 9) que "quanto mais conhecemos a organização geral da sociedade, seus diferentes grupos e interesses, seus valores e suas instituições coleti- vas, mais capacidade temos de intervir na realidade e transformá-la”.

A antropologia, por sua vez, teria como objetivo estudar as formas de cultura humana, possibilitando dar voz àqueles considerados geralmente os "outros", reconhecendo o outro em sua diferença, sem que implique em julgamento de valor (BOMENY, et al., 2013). No exercício proposto pelas autoras no quadro "monitorando a aprendizagem” (p. 48), se deseja que o aluno reflita como este conhecimento pode contribuir para o conhecimento da sociedade em que ele faz parte.

Afirma-se que as áreas das ciências sociais estão interligadas, possuindo indagações em comum. 0 ponto chave é que estas áreas

[...] contribuem para modificar a nossas maneira de viver, olhar o mundo [...]. Observar nosso ambiente mais próximo e refletir sobre ele é uma qualidade humana adquiria ao nos aproximarmos do imenso e complexo campo de estudos no qual a Sociologia, objeto deste livro, se inclui de forma particular. Entender a lógica dessas situações é um passo importante para orientar nossa posição no mundo e a percepção a respeito do nosso lugar como indivíduos no conjunto maior. É dar sentido pleno a expressão cunhada por Wright Mills - a imaginação sociológica -, parceira inseparável do esforço para levar a Sociologia aos jovens. (BOMENY, et al., 2013, p. 63).

Sendo assim, o livro Tempos Modernos, Tempos de Sociologia contempla o sentido de sociologia voltado para o desenvolvimento da imaginação sociológica, o que se faria fundamentalmente pela aproximação dos conhecimentos do senso comum ao campo de conhecimento intelectual das ciências sociais. A expressão da ciência não é afırmada com frequência (e nem como 
metodologia a ser exercitada pelos alunos), tampouco são utilizadas explicitamente as noções de estranhamento e de desnaturalização. Além disso, tem-se que a sociologia se mostra uma ferramenta importante para a mudança social.

\subsection{Sociologia - ARAÚJO, BRIDI, MOTIM, 2013}

O livro Sociologia foi elaborado por Silvia M. de Araújo, Maria Aparecida Bridi e Benilde Lenzi Motim, todas graduadas em ciências sociais e vinculadas ao ensino superior pela Universidade Federal do Paraná (UFPR) ${ }^{17}$. Da trajetória das autoras, verifica-se que as mesmas elaboraram diversos materiais didáticos, sendo livros e apostilas de sociologia e filosofia, voltados para o nível básico e para o superior, como o Sociologia: um olhar critico", de 2009. De todos os autores dos livros analisados neste artigo, estas são as autoras que mais produziram materiais didáticos.

No entanto, ainda que a produção de materiais didáticos seja em maior número, isto não reflete a maior participação no subcampo do ensino de sociologia. Não foram localizados trabalhos acadêmicos sobre o ensino de sociologia (à exceção de Benilde Motim) ou participação nos eventos da área. Da mesma forma, nenhuma das autoras lecionou no ensino básico na área de sociologia ${ }^{18}$, focalizando a carreira no ensino superior e na pesquisa (especialmente na temática da sociologia do trabalho).
Os propósitos do ensino de sociologia, neste interim, coincidem com os objetivos da sociologia enquanto campo científico, em termos mais gerais. 0 livro de Araújo, Bridi e Motim (2013) está organizado na forma de capítulos (10, no total), podendose afirmar que a sociologia é o fio condutor, sendo a antropologia e a ciência política parte de alguns dos temas destacados pelas autoras. Em resumo, "as ciências sociais se dedicam a estudar a cultura, o poder e as relações sociais" (p. 11), abarcando assim as três áreas clássicas. Cabe às ciências sociais analisar e explicar o que está acontecendo no âmbito político, econômico, cultural e social, indagando-se o tempo todo sobre o que rompe as estruturas antigas e o que se constitui de novo na sociedade.

Os dois capítulos iniciais propõem-se a apresentar a sociologia e os seus objetos de interesse, partindo dos conceitos dos clássicos - como Durkheim, Marx e Weber -, e abrangendo outros autores ${ }^{19}$. Em especial, são colocados os principais problemas com que as ciências sociais se defrontam e as suas contradições, como parte do processo de construção do conhecimento. A partir disso, as temáticas que estão relacionadas às ciências sociais e à vida moderna dos jovens, como: família, trabalho, cultura, religião, cidadania, movimentos sociais, educação e transformação social, juventude e o meio ambiente.

De acordo com este livro didático, as ciências sociais se opõem ao senso comum (tido como um conhecimento prático, do cotidiano), possibilitando sair do mundo,

17. Sílvia M. de Araújo é professora aposentada da UFPR. Juntamente com Helena Bomeny e Nelson Tomazi, são as autoras de maior antiguidade na conclusão da graduação (ano de 1991).

18. Maria Aparecida Bridi lecionou geografia e história.

19. Há em outros capítulos a definição mais específica da antropologia, que auxiliam a ampliar o nosso conhecimento sobre outras culturas e expressões, auxiliando a relativizar a nossa visão de mundo (ARAÚJO; BRIDI; MOTIM, 2013, p. 129), e de ciência política, que se dedica ao estudo dos fenômenos da política, do Estado, dentre outros (ARAÚJO; BRIDI; MOTIM, 2013, P. 191). 
em particular, e articular outras dimensões da vida em sociedade. Pensar sociologicamente implica distanciar daquilo que nos é familiar, questionando o que é dado como natural e inevitável - ou seja, os conceitos de estranhamento e desnaturalização. Então, o objetivo da sociologia é pensar e cultivar a "imaginação sociológica", posto que, com as questões suscitadas pelas ciências sociais, "conduzem a processos de construção de cidadania, vislumbrando nossos direitos e deveres" (ARAÚJO; BRIDI; MOTIM, 2013, p. 4). A imaginação sociológica é retomada posteriormente (p. 33), como um elemento importante para se pensar a relação entre a forma que a sociedade se organiza e os acontecimentos cotidianos na vida dos indivíduos, entre um problema social e uma questão individual.

A separação com o senso comum é mais claramente apresentada no Capítulo 2, que se dedica a apresentar a formação histórica da sociologia. Araújo, Bridi e Motim (2013, p. 42-44) apresentam distintas sociologias praticadas inicialmente com a sociologia institucionalizada, ou seja, uma sociologia científica (que também é colocada como múltipla, em teorias e em métodos). 0 senso comum, conforme essas autoras (p. 46-47), é o conhecimento mais imediato e limitado às ações espontâneas e não refletidas. A ciência, por sua vez, é a busca e a descoberta com base em métodos definidos e em teorias coerentes, que visam conhecer a sociedade e transformar a realidade social. As autoras, porém, ponderam que o senso comum pode ser base da ciência (ponto de partida), apontando que algumas vertentes da sociologia já o têm reconhecido como um conhecimento válido e enriquecedor.

Preconiza-se que a construção do conhecimento seja feita ativamente pelos alunos e pelo professor, estimulando a crítica social, o que faz parte da descoberta da identidade do aluno, podendo o livro contribuir neste sentido (ARAÚJO; BRIDI; MOTIM, 2013, p. 4). Vale colocar, ainda, que para as autoras, o sociólogo é um agente social ativo que reflete sobre a sociedade em que vive e fornece os instrumentos necessários para que outros indivíduos possam pensar a sua realidade e experimentar uma avaliação de valores. Há um "sentido cultural das ciências sociais", assim colocado pelas autoras:

Cabe ao sociólogo, portanto, como agente social ativo, desenvolver uma reflexão para criticar a sociedade em que vive, levando os indivíduos a pensar a sua realidade social, experimentando uma avaliação de valores e compreendendo o sentido cultural das Ciências Sociais. (ARAÚJO; BRIDI; MOTIM, 2013, p. 33)

As ciências sociais são guiadas por métodos, por objetivos e pela curiosidade. Para as autoras (ARAÚJO; BRIDI; MOTIM, 2013, p. 9), a sociologia tem como principais objetivos demonstrar que os fenômenos como desigualdades, pobreza, estratificação social, não são naturais, desnaturalizando os fenômenos para desvelar os mecanismos de dominação social. No caso brasileiro, a sociologia também "se firma como ciência em resposta às indagações da sociedade, descortinando a diversidade cultural, as desigualdades sociais, as diferenças regionais" (p. 26). Questionar as estruturas desiguais das sociedades, desnaturalizando-as, é uma das principais tarefas da sociologia. 0 aluno, neste ínterim, é convidado a se colocar como um sujeito que se indaga, reflete e investiga a sociedade em que vive.

Pode-se apontar que a maior cisão entre o conhecimento científico e o ensino de sociologia se dá a partir do imbricado entre o conceito de cidadania e a proposição 
de atividades. Isto porque de um lado há a sociologia científica, que é questionadora e provocadora de críticas sociais, enquanto de outro, o ensino de sociologia visa promover a atuação do alunado na sociedade.

A relação da sociologia com a cidadania é trabalhada neste livro didático em diversos momentos, articulando-se tanto com a finalidade da própria sociologia quanto com uma temática da área. A cidadania como tema é especificamente trabalhada no Capítulo 7, intitulado "Cidadania, Política e Estado", atrelando-a como a conquista de direito e de deveres, e que ela se define fundamentalmente pela "participação ativa do cidadão" (ARAÚJO; BRIDI; MOTIM, 2013, p. 171).

A sociologia participa da formação do cidadão, conduzindo para a mobilização e para a transformação da sociedade, pois, conforme afırmam Araújo, Bridi e Motim (2013, p. 200) "como você já sabe, as ciências sociais se preocupam com a participação dos indivíduos em sociedade - e, consequentemente, com uma das bases para o exercício da cidadania”. É da própria sociologia instrumentalizar os alunos para a transformação social, o que é confırmado na atividade apresentada ao aluno: "qual a importância do conhecimento sociológico para entender a sociedade e poder transformá-la?” (p. 61). As próprias temáticas ligadas à sociologia e a forma de se estudar esta disciplina estariam implicitamente fomentando a participação cidadã: "estudar Sociologia nos introduz em um atraente universo de questões e nos convida a participar da sociedade como cidadãos” (p. 33).

A pesquisa, como parte da atividade do apreender a sociologia e intervir na realidade social, participa de todos os capítulos do livro. As autoras incluem quadros de pesquisa e debates, fazendo com que os alunos passem a coletar materiais de apoio e rea- lizem pesquisas bibliográficas (em livros, internet, jornais, revistas), além de incentivar a realização de entrevistas e enquetes. Ao final das buscas, o aluno é orientado a produzir algum material (a depender da atividade), traduzindo os dados coletados em alguma reflexão, sob a sua percepção.

Tomando a sociologia como instrumentalizadora para a transformação da realidade social, as autoras procuram por meio dos exercícios e sugestões de pesquisa que o aluno aponte sugestões para a atuação na sociedade, para a sua mudança. Assim, alguns exemplos são extraídos, como: apontar "sugestões para mudar a realidade encontrada” (ARAÚJO; BRIDI; MOTIM, 2013, p. 109); propor ao aluno que "procure saber sobre as diferentes possibilidades de participar politicamente”, "na reivindicação de nossos direitos; [...]” (p. 196); propor medidas ao Estado brasileiro de promoção de desenvolvimento econômico assegurando igualdade de renda, emprego e preservação do meio ambiente (p. 290); “que ações dos movimentos sociais no Brasil e no mundo vocês acham que podem ajudar a melhorar a situação das pessoas em cada uma dessas condições [da proposta]?” (p. 217).

Enfım, o livro de Araújo, Bridi e Motim (2013) contempla todas as noções indicadas para a análise do trabalho, mas atribuem um peso diferente a determinados aspectos. Nesta visão, é isto que a faz cindir entre a sociologia acadêmica e o ensino de sociologia propriamente dito, este que tem a finalidade, segundo as autoras, de promover a transformação social, com a formação para a cidadania.

\subsection{Sociologia em movimento - SILVA et. al., 2013}

0 livro Sociologia em movimento integra uma gama de autores (19 no total) que 
fazem parte, ou fizeram, à época da divulgação do livro do Colégio Pedro II, no Rio de Janeiro ${ }^{20}$. Assim sendo, estes autores estão imbricados com o ensino de sociologia em sua prática na escola, ao mesmo tempo em que não deixam, em razão da estrutura do Colégio, de estar envolvidos com a pesquisa acadêmica.

Nota-se que todos os autores possuem graduação em ciências sociais, e a maioria em instituições públicas localizadas no Rio de Janeiro, sendo apenas cinco que não possuem licenciatura. 0 envolvimento com o ensino básico também tem reflexo na titulação dos autores, variando de graduados a pós-doutores, sendo que 9 possuíam mestrado completo à época, em diversas áreas afeitas às ciências sociais. No contexto do Colégio Pedro II é que os professores são francamente integrados com a pesquisa, possuem uma revista própria - Perspectiva Sociológica -, seminários e produções no subcampo de alunos e professores.

Há autores que produzem no subcampo do ensino de sociologia ou em outros espaços (outras instituições), sendo que o magistério em ensino superior também se faz presente nos currículos dos autores. Mesmo assim, percebe-se que são aqueles que estão no entorno do Colégio Pedro II, ainda atualmente, que se mantêm atuantes no subcampo.

Um “espírito" integrador de campos pode ser percebido na organização e na proposta do livro didático. 0 livro de Silva et al. (2013) está dividido em 6 unidades e 15 capítulos, de modo que "a obra está estruturada segundo a proposta pedagógica que visa possibilitar a interação do leitor e mobilizar o estudante para a reflexão, a pesquisa e a leitura" (BRASIL, 2014, p. 36). A organização das unidades é colocada de modo a contemplar a sociologia, apresentando-se a disciplina e seus pressupostos, passando pela antropologia e pela ciência política. Estes três componentes das ciências sociais não estão separados, mas se entrelaçam nas temáticas e nos eixos teóricos, como: "Cultura e sociedade: cultura, poder e diversidade nas relações cotidianas" da Unidade 2; "Relações de poder e movimentos sociais: a luta pelos direitos na sociedade contemporânea”, da Unidade 3, além de outros.

A questão da autoria é evidenciada na Apresentação, explicitamente ao colocar que "uma característica importante deste livro é ter sido escrito por mãos calejadas pela prática docente." (SILVA et al., 2013, p. 3), o que contribuiria para apresentar a sociologia enquanto disciplina com temas e discussões próprias combinadas às inquietações e demandas atuais dos jovens.

Nesta mesma breve Apresentação ao aluno, os autores indicam que o livro se presta a ser instrumento para formular "as questões importantes para a nossa sociedade atual e estabelecer os critérios para criar soluções possíveis, sempre amparados pelo campo científico das Ciências Sociais" (SILVA et al., 2013, p. 3). A sociologia, em contínuo, oferece as ferramentas necessárias para a compreensão e a apropriação da realidade, fazendo entender que os problemas com os quais lidamos não são determinados pela natureza, mas são socialmente construídos. 0 aluno deve ser capaz de "utilizar as Ciências Socais como meio de

20. 0 Colégio Pedro II é uma das mais tradicionais instituições de ensino do país. Foi fundado em 1837 e desde 2012 foi equiparado às Instituições Federais, tendo atualmente 14 campi e atuação também na pósgraduação (lato e stricto sensu). 
conhecer cientificamente a realidade social" (p. 10).

A noção de sociologia enquanto ciência é apresentada de modo histórico, para a compreensão do contexto de formulação do conhecimento científico moderno, e mais especificamente para localizar o campo científico das ciências sociais. A sua finalidade enquanto ciência é destacada por Silva et al. (2013, p. 11) em buscar "compreender a realidade e propor soluções para os inúmeros conflitos sociais contemporâneos", destacando as três áreas que compõem esta disciplina. Para os autores, a sociologia nasce diante do espírito de insatisfação e de luta por melhores condições de vida, buscando conhecer as causas das desigualdades sociais e buscar soluções racionais. Este seria o sentimento que moveu e ainda move o desenvolvimento das ciências sociais.

Segundo Silva et al. (2013), o conhecimento científico se produz por meio de regras e de critérios sistemáticos de investigação e verificação, sendo hoje o principal modo de produção do conhecimento e de promover a transformação da realidade. A ciência seria considerada "atualmente a maneira mais adequada de produção de conhecimento sobre a realidade" (p. 14) e a que detém, no caso das ciências sociais, diferentes métodos de análise da realidade social. No entanto, os autores apresentam diferentes correntes que discutem a ciência e o senso comum, vistas como opostos ou, por vezes, como complementares e conectadas. 0 que é essencial para esses autores é que a sociologia produza seu saber enquanto ciência, com métodos de investigação, o que poderá ser apreendido pelo senso comum para apresentar soluções objetivas para problemas específicos.

Fazendo referência mais direta à Lei de Diretrizes e Bases (LDB), no livro (SILVA et al., 2013, p. 230) preconiza-se a construção de uma "visão crítica e reflexiva da realidade", através de instrumentos como informação, vivências e experiências, como fatores decisivos para a formação dos jovens e dos adolescentes, aliando assim ferramentas para a crítica e para o conhecimento imediato (do senso comum).

Assim, a sociologia é defınida:

Sociologia. Ciência que tem papel importante na explicação e interpretação dos fenômenos e eventos ocorridos na sociedade contemporânea. É utilizada como base para a reflexão em diferentes áreas do conhecimento, da Medicina ao Direito. 0 conhecimento acumulado por essa disciplina permite traçar um panorama bastante amplo sobre os problemas na sociedade em que vivemos. Desde 2008 é disciplina obrigatória na grade curricular dos alunos da Educação Básica no Brasil, tendo um papel central na formação e reflexão crítica desses alunos sobre os contextos nos quais estão inseridos (SILVA et al., 2013, p. 20).

Dentro desta perspectiva científica, a antropologia também é defınida como disciplina científica, dedicada ao estudo da diversidade de culturas e de sociedades diferentes pelo mundo (SILVA et al., 2013, p. 60). É no contexto dos estudos sobre cultura que o conceito de estranhamento é mobilizado, como um pressuposto de poder avaliar a importância do contexto cultural. A desnaturalização, por sua vez, embora não colocada explicitamente, é indicada na ideia de questionamento da "naturalização do preconceito” (p. 107). É próprio então da reflexão sociológica o "discutir criticamente a formação histórica, social, econômica e política” de determinados conceitos (p. 105).

Ao trazer a necessidade dos métodos para a composição de um campo científico, 
os autores destacam que as ciências sociais também possuem métodos próprios e partem de teorias também diversas. Segundo Silva et al. (2013), os métodos são necessários para o pesquisador objetivar seus próprios valores e ideias, que antecedem a pesquisa e condicionam a escolha do objeto e problema definidos.

Para Silva et al. (2013), as ciências sociais têm abordagens tanto quantitativas, quanto qualitativas, descrevendo o que trata cada uma delas e as formas de pesquisa social (entrevista, questionário, uso de dados). A preocupação colocada é fazer o aluno compreender o modo de construção do saber científıco, através da descrição de métodos, da construção de hipóteses, da definição de campo e da utilização de técnicas de pesquisa. A pesquisa, assim, é apresentada neste manual como elemento fundamental para a construção do saber sociológico, conforme já colocado por Oliveira e Cigales (2015, p. 285) que "este manual, diferentemente dos outros vistos até aqui, busca conciliar a pesquisa metodológica como base de aplicação dos conteúdos teóricos”.

Destaca-se que a cada capitulo há a indicação nas atividades do quadro "Questões para Pesquisa”, em que, embora tenha um cunho também informativo (que os alunos busquem informações em sites, revistas, jornais), é aliado à pesquisa com os elementos teóricos estudados. Para além deste quadro, há outras sugestões de atividades que também incluem pesquisa de caráter informativo e também investigativo, fazendo com o que o aluno colete dados e produza alguma proposta de trabalho, auxiliando-o na reflexão e na aplicação dos conteúdos estudados no capítulo.
Chama-se atenção também para a sugestão de pesquisa com a finalidade de propor ações sociais que visem à mudança de determinada situação percebida. 0 quadro "MovimentAção", presente ao final das unidades, geralmente se constitui em uma formulação de um projeto de trabalho maior; constitui-se de uma pesquisa mais robusta - em termos de levantamento de dados e de elaboração de sínteses -, com a finalidade de pesquisa, de reflexão temática e de atuação social. Assim, se propõe à "realização de uma campanha em defesa dos direitos da criança e do adolescente" (SILVA et al., 2013, p. 54); “organizar uma campanha contra as formas de preconceito e discriminação” (p. 132); “pensar ações que solucionem os problemas da comunidade" (p. 211); usar a arte para "inspirar propostas de reflexão e transformação da realidade" (p. 258); entre outros.

Este livro ainda apresenta, em todos os seus capítulos, um quadro denominado "Instrumento Jurídico", em que são alocados textos de leis, comentários sobre a legislação e questões para reflexão e pesquisa do aluno. Percebe-se que este quadro atribui à sociologia o papel em informar ao aluno quais os direitos e os deveres existentes na lei. A questão jurídica (informativa) é também colocada dentro dos capítulos e destaca a importância do reconhecimento dessas legislações como conquistas sociais $^{21}$. A partir destas legislações, o aluno é convidado a perceber quais leis estão sendo ou não cumpridas, como, por exemplo, a sugestão de atividade de "elaborar um relatório de visitas, do qual constará se todas as leis trabalhistas citadas nesta seção estão sendo cumpridas pela empresa" (SILVA, et 
al., 2013, p. 230), ou verificar "violações da lei” (p. 184). Essa visão está apoiada no desenvolvimento da questão da cidadania, como um papel de formação do cidadão, este, detentor de direito e de deveres, e que luta por eles.

A sociologia não se apresenta explicitamente ligada à cidadania, mas por meio dos quadros jurídicos e do fortalecimento da visão de uma cidadania formal, mais explicitamente trabalhada no Capítulo 7. 0 conceito de cidadania é visto por Silva et al. (2013, p. 158) como não fixo, estando "em curso no Brasil uma nova consciência de cidadania e participação popular”, preconizando a compreensão dos movimentos sociais e da sua importância para a construção de uma sociedade democrática.

As noções de intervenção social estão presentes em outros momentos, para além da pesquisa. As questões motivadoras de alguns capítulos são colocadas como finalidade de pensar ações para a transformação social, como "por que o racismo persiste no Brasil e como podemos combatê-lo?" (SILVA, et al., 2013, p. 103), e pensar em como promover o desenvolvimento econômico aliado ao respeito à diversidade, ao meio ambiente e diminuindo as desigualdades sociais. Do mesmo modo, sugere-se apresentar propostas para o aperfeiçoamento da democracia brasileira e como elas podem "colaborar para as mudanças na sua rua e/ ou no seu bairro" (p. 187).

Desta feita, é possível concluir que no livro de Silva et al. (2013) a sociologia é apresentada pela vertente do conhecimento científico, dotado de métodos próprios e que se vale do estranhamento e desnaturalização, mas que não se opõe ao senso comum. A sociologia fornece os instrumentos ao aluno para que ele possa voltar-se ao cotidiano e atuar socialmente, apresentan- do soluções para os problemas sociais investigados. A sociologia se interessa pela transformação social como um fenômeno social, possibilitando (com o seu conhecimento científico) a apropriação das suas investigações e reflexões para a ação social

\subsection{Sociologia Hoje - MACHADO, AMO- RIM, BARROS, 2013}

O livro Sociologia Hoje foi concebido por três autores que, nos termos delimitados neste trabalho, apresentam o maior afastamento do subcampo do ensino de sociologia, não indicando que possuem pesquisas ou participação em eventos que envolvam o ensino de sociologia.

Chama atenção, ainda, que no currículo Lattes desses autores não há menção à expressão "livro didático" ou "material didático" junto à informação da publicação, também dispensando este dado no "texto informado pelo autor”. Igualmente, nenhum dos autores foi professor de ensino básico, não havendo indicativo acerca da realização da licenciatura. Assim, não foram localizados indícios que os autores tenham alguma relação, para além da produção do livro, com o subcampo do ensino de sociologia.

Melhor situando os autores, Igor Machado, Henrique Amorim e Celso de Barros têm elo através da Universidade Estadual de Campinas (UNICAMP), sendo graduados em ciências sociais nessa instituição. À exceção de Celso de Barros (doutor em Oxford, Inglaterra), os demais são doutores na mesma área e universidade, sendo professores universitários na Universidade Federal de São Carlos (UFSCar) e na Universidade Federal de São Paulo (UNIFESP), respectivamente. Celso de Barros, por sua vez, é atualmente colunista do jornal Folha de São Paulo e servidor do Banco Central 
do Brasil, não havendo atualização do seu currículo desde 2015, indicando que há um afastamento do campo acadêmico. Vale ainda dizer que a área de interesse dos autores transita entre os três eixos das ciências sociais: a antropologia, a sociologia e a ciência política.

Desta feita, ressalta-se que o livro Sociologia Hoje é conhecido justamente por possuir uma maior separação entre essas três áreas, o que já foi observado por Desterro (2016). 0 guia do PNLD (BRASIL, 2014) também apontou para este diferencial, por trazer mais claramente a fundamentação e a divisão dessas três áreas das ciências sociais trabalhando-as em unidades especificas e independentes.

Assim, no primeiro momento, as ciências sociais são introduzidas ao aluno, passando na Unidade 1 para Cultura, na Unidade 2 para Sociedade e na Unidade 3 para Poder e Cidadania. A antropologia é definida como "a ciência que busca entender como o ser humano pode levar vidas tão diferentes" (MACHADO, AMORIM e BARROS, 2013, p. 14), a sociologia pretende "entender cientificamente os fenômenos da vida social" e a ciência política "dedica-se ao estudo da política e das formas de poder" (p. 15).

0 principal objetivo apresentado no livro é “aproximar as investigações, reflexões e teorias das Ciências Sociais do seu [do aluno] cotidiano, como um instrumento de reflexão crítica sobre o seu dia a dia, a sociedade em que você vive, sua história e o mundo contemporâneo" (MACHADO, AMORIM e BARROS, 2013, p. 3). Além disso, se espera que o aluno possa, por meio de um aprendizado crítico, ajudar na "construção de um mundo mais justo e feliz para todos, vivendo plenamente sua cidadania” (p. 3).

Os conceitos de estranhamento e desnaturalização são também colocados pream- bularmente, possibilitando que os alunos questionem a naturalização dos fenômenos por meio das atividades propostas. Mais adiante, Machado, Amorim e Barros (2013, p. 52 e 87) reforçam este conceito, especialmente ligado à antropologia, que possibilita que práticas culturais diversas sejam consideradas legítimas.

A introdução à sociologia parte da ideia que as ciências sociais se interessam por entender como acontece a vida em sociedade, questionando-se continuamente. Assim, o aluno é convidado a formular alguma pergunta sobre a vida em sociedade, como um ponto de partida, ao pensar sociologicamente. No entanto, as ciências sociais, enquanto ciência, fazem 'boas perguntas' sobre a vida social, sob diferentes olhares e perspectivas, e por critérios diversos entre suas áreas (não há um consenso, mas linhas de estudos e teorias).

0 pensamento crítico é colocado como um dos objetivos das ciências sociais, definido como "a capacidade de desvendar mecanismos que, embora operem como se fossem naturais, nada têm de naturais" (MACHADO, AMORIM e BARROS, 2013, p. 10). Esta definição está novamente ligada ao conceito de desnaturalização, explicitamente apresentado por esses autores. Deve-se destacar que ao longo dos capítulos há quadros de reflexão intitulados "Você já pensou nisto?”, em que se possibilita continuamente que o aluno pense o seu cotidiano, suscite questionamentos e pratique o estranhar e desnaturalizar das relações sociais.

Para os autores, as ciências sociais são uma ferramenta para entender o mundo, construindo o seu saber por meio de perguntas e de métodos, e de objetivação do pesquisador. As ciências sociais são ciências porque "elaboram métodos sistemáticos e 
testam detalhadamente suas hipóteses", diferenciando-se assim do senso comum (MACHADO, AMORIM e BARROS, 2013, p. 12). Assim, esta ciência se vale de um pensamento sistemático, formulando hipóteses, questões, temas e meios de investigação dos fenômenos. Para Machado, Amorim e Barros, se faz ciências sociais por meio de conceitos e métodos, que se pretendem precisos, o que não ocorreria com os conceitos do cotidiano, que não têm o controle da comunidade científica. Apesar dos conceitos científicos não serem estáticos, eles se modificam por meio de investigações sistemáticas, adequadas ao método mais objetivo, apresentando aos alunos modos de pesquisar, quantitativos e qualitativos.

Voltando ao pensamento crítico, para os autores o sentido de produção do conhecimento das ciências sociais está na "utilidade da informação produzida e a utilidade de aprender a pensar criticamente" (MACHADO, AMORIM e BARROS, 2013, p. 20). Ou seja, o trabalho do cientista social deve impactar na vida social, como construção de políticas públicas, e deve ter impacto pessoal, provocando mudanças na forma de pensar das pessoas. Assim, a sociologia, enquanto ciência fornece os instrumentos necessários para estes impactos.

A sociologia enquanto disciplina escolar possibilita fornecer ao aluno estes instrumentos, para que ele possa refletir criticamente, com autonomia e decifrando o mundo: "exercitar o pensamento crítico prepara você para não se deixar enganar facilmente, e por isso a ciência social pode ser muito útil" (MACHADO, AMORIM e BARROS, 2013, p. 21).

No conceito de cultura, colhido na Unidade 1, faz-se uma importante reflexão que auxilia a pensar os sentidos das ciências sociais: "para que serve o conheci- mento produzido pelas Ciências Sociais?" (MACHADO, AMORIM e BARROS, 2013, p. 31). A resposta inova em relação aos outros livros, colocando-se que as ciências sociais servem também para dominar, como se viu/vê especialmente em estudos do evolucionismo social e etnocêntricos, embora criticados posteriormente, havendo outras vertentes e discussões atualmente. Desta forma, para estes autores a sociologia não é iminentemente crítica, havendo diferentes correntes e teorias, podendo (a depender do contexto) fornecer ferramentas para pensar criticamente.

A noção de cidadania, por sua vez, é trabalhada no livro didático como um conteúdo afeito mais propriamente à ciência política, sendo mobilizado mais claramente no Capítulo 13, "A sociedade diante do Estado". Os autores signifıcam a cidadania para além da questão da identidade nacional e da questão de portar direitos e deveres.

Observa-se que a vivência da cidadania é, nesta obra, uma consequência do pensar criticamente. Não foram localizadas formulações de "práticas cidadãs", havendo questionamentos de práticas em forma de compartilhamento de experiência de atuação na comunidade. Isto pode estar relacionado com ausência de práticas de pesquisa. No livro analisado, as proposições de pesquisa se dão em caráter informativo, como conversa, busca de informações, com o fim reflexivo e geralmente alocado nas indagações do quadro "Você já pensou nisto?”, ao longo dos capítulos.

\subsection{Sociologia para jovens do século XXI - OLIVEIRA, COSTA, 2013}

0 livro didático de Oliveira e Costa (2013) é resultado de diversas formulações, estando na sua $3^{\text {a }}$ edição. Porém, as edições 
anteriores, realizadas pelos mesmos autores e que carregam outra denominação ${ }^{22}$, também compõem, ao final, a obra analisada no PNLD 2015. Por meio do desenvolvimento de seu trabalho junto ao ensino básico, os autores voltaram-se à formulação de materiais didáticos para o ensino de sociologia, sendo fortemente atuantes no subcampo do ensino de sociologia.

A participação no campo da sociologia é percebida pela presença dos autores nos GTs do livro didático no Encontro Nacional de Ensino de Sociologia na Educação Básica (ENESEB) e outros eventos, coordenação de livros coletâneas na área, produção de artigos e elaboração de materiais didáticos. Apesar de Luiz Oliveira não possuir licenciatura (sua graduação é em sociologia, na Itália), ambos os autores lecionaram para o ensino básico, sendo Ricardo Costa vinculado ao Instituto Federal do Rio de Janeiro (IFRJ), mantendo a atuação no magistério da educação básica.

De fato, Luiz Fernandes Oliveira, por sua titulação (Doutor em Educação pela PUC Rio) e vinculação ao ensino superior pela UFRRJ, atuando como professor de pósgraduação, transita com maior força junto ao ensino de sociologia enquanto campo de pesquisa. 0 próprio autor, em sua produção acadêmica, defende a consolidação da sociologia como disciplina escolar (legitimação na escola, por seus conteúdos), e também pela consolidação do ensino de sociologia como um campo de pesquisa com construções e objetivos próprios.

Assim, o livro didático Sociologia para jovens do século XXI tem a preocupação de situar o conhecimento sociológico em uma linguagem que se faça acessível aos alunos. 0 guia do PNLD (BRASIL, 2014, p. 45) indica esta valorização da linguagem jovial contida na perspectiva dialógica, que é marca da obra. Os eixos norteadores do livro, segundo o guia, são o senso comum e a desnaturalização da realidade social. 0 livro é organizado em três grandes unidades: "Sociedade e Conhecimento Sociológico", “Trabalho, Política e Sociedade", e "Relações Sociais Contemporâneas”, num total de 22 capítulos.

Introdutoriamente, Oliveira e Costa (2013) apresentam esses eixos, tomando a preocupação de superar o senso comum ideias que se baseiam na aparência das coisas, sem uma reflexão apurada. Para esses autores, a sociologia tem uma dupla tarefa: problematizar opiniões que venham do senso comum, e desnaturalizar a realidade social, o que implica no estudo criterioso, de base científica. Ainda segundo eles, o livro é formulado de modo a apresentar os fatos e as ideias da vida cotidiana, introduzindo a partir daí os conceitos sociológicos, justamente para realizar um afastamento do senso comum (que é o ponto de partida). Os objetivos são assim descritos:

Queremos apresentar aos jovens conteúdos que construam um saber crítico, dinâmico e problematizador das noções do senso comum. Crítico, porque visa a inserção consciente dos jovens no mundo à sua volta; dinâmico, por incentivar a participação política e social consciente na realidade social brasileira; e, por fim, problematizador, por questionar os discursos naturalizadores de uma realidade social marca por profundos problemas éticos, sociais e econômicos. (OLIVEIRA; COSTA, 2013, p. 4) 
Definindo o senso comum, Oliveira e Costa (2013) afirmam serem as opiniões pessoais, generalizantes, que julgam fatos específicos como se fossem fatos universais. 0 senso comum é reafirmado ao longo do livro como algo que deve ser refutado, que é investido por preconceitos, acrítico e determinado por muitos interesses.

A tarefa teórica da sociologia é, por sua vez, contrapor a visão que dominaria o senso comum, que considera utilidade o que dá mais prestígio e o que a maioria considera como ações práticas. Oliveira e Costa (2013) apontam a importância do "olhar sociológico" para perceber os interesses que estão em jogo em determinada relação social.

Ao final do livro, Oliveira e Costa (2013) retomam a finalidade da sociologia de não se deixar guiar pelo senso comum, auxiliando na instrumentalização por conhecimentos que tornam conscientes as ações cotidianas dos homens e das mulheres. Ela mexeria com as certezas, desafiando opiniões e podendo conduzir à mudança social.

A sociologia, enquanto disciplina, estuda as relações sociais e questiona sobre o comportamento dos indivíduos e dos grupos sociais, de modo a refletir o porquê dos conflitos, das regras e de seus descumprimentos, dos rearranjos, etc. Situando a ideia de imaginação sociológica, Oliveira e Costa (2013) a apresentam como uma qualidade do espírito humano que ajuda a perceber o que está acontecendo no mundo e como se situar nele. É ter consciência da existência de uma estrutura de sociedade, das relações sociais, possibilitando pela imaginação sociológica a identifıcação das ligações com a experiência cotidiana. A sociologia, neste sentido, auxilia a refletir sobre o cotidiano, repensando a nossa visão de mundo. A sociologia pode instrumentalizar "com co- nhecimentos para nos tornarmos conscientes de nós mesmos e das ações de homens e mulheres que desejam profundamente liberdade e felicidade" (p. 18).

Os pressupostos epistemológicos dos autores ficam expressos nos questionamentos suscitados ao longo dos capítulos, participando da intenção de tomada de consciência. Assim, destacam-se alguns excertos:

[...] e como é hoje, num mundo neoliberal, onde o desejo dos capitalistas em privatizar tudo e flexibilizar ao máximo as relações de trabalho, com o objetivo de aumentar a acumulação de capital pelas grandes empresas? (OLIVEIRA; COSTA, 2013, p. 224);

[...] ele [o presidiário], agora, com acesso ao celular, pode organizar roubos, sequestros e até fugas e rebeliões. Você se lembra do papel que o celular passou a ter, de uns tempos para cá, nas rebeliões de presidiários? Basta assistirmos aos noticiários diários (OLIVEIRA; COSTA, 2013, p. 254).

Neste sentido, estas expressões de religiosidade colocam para todos nós que, ou viveremos numa sociedade multicultural, em que todos respeitem as diversidades humanas, ou sucumbiremos aos totalitarismos, intolerância e racismos (OLIVEIRA; COSTA, 2013, p. 311).

Com isso, a reflexão sociológica levaria à intervenção social, propondo modos de participação social e política do aluno, exemplificando-se: "você também pode ajudar a moldar ou modificar as instituições”; “é possível resolver a crise do emprego somente com a abertura de novas escolas técnicas ou a partir da obtenção de um diploma de Ensino Médio ou, principalmente, de nível superior?”; “como você, estudante, se situa em relação à política: 
como de direita, de centro ou de esquerda? Por quê?"; "você [...] participaria ou organizaria um movimento para transformar uma situação que afeta negativamente a todos?”; “o que devemos fazer então? Ser dissimulados? Fingir que o racismo não existe? Ou encarar de frente essa questão, para construirmos juntos (brancos, negros, amarelos etc.) um Brasil sem racismo?"; organizar um trabalho a ser apresentado para a escola "e que possa contribuir para o fim da discriminação racial", "quais poderiam ser os mecanismos de luta contra as ideologias machistas e homófobas?”, “quais seriam as soluções para se combater o crime organizado [...]?" respectivamente colocadas por Oliveira e Costa (2013, p. 46, 176, 227, 243, 280, 282, 297, 357).

Destacamos, ainda, que o livro de Oliveira e Costa (2013) não trabalha com a pesquisa sociológica propriamente dita, sendo estas questões colocadas ao longo do capitulo ou nas atividades. As pesquisas sugeridas são de caráter consultivo e bibliográfico.

Por fim, anotamos que a noção de cidadania não aparece interligada com uma finalidade da sociologia, mas sim como uma temática, trabalhada mais especificamente no capítulo 13 - "É de papel ou é pra valer? Cidadania e direito no mundo e no Brasil Contemporâneo". A perspectiva colhida de cidadania é histórica, em seus diferentes significados e imbricados com as lutas sociais para a conquista de direitos. Nos capitulos seguintes também há referências à cidadania, significando-a diferentemente, conforme o contexto trabalhado.

\section{Considerações finais}

Ao longo desse processo descritivo-analítico, observaram-se inúmeros pontos de convergências no que tange às concepções de sociologia presentes nos livros didáticos, o que pode ser explicado em parte pela busca em adequação dos livros didáticos às normas do próprio edital do PNLD, de modo que a submissão do livro à avaliação do programa poderia ter como um dos efeitos não intencionais a produção de um determinado "modelo" de produção do livro didático. Todavia, compreende-se isso como um processo dinâmico, uma vez que o livro de Tomazi, ainda que aprovado nos editais de 2012 e 2015 , foi reprovado no edital de 2018.

Outro aspecto que deve ser considerado nesse processo é que, para além de uma dimensão estritamente autoral, os livros didáticos, devido à sua forte inserção no mercado editorial, são produzidos a partir da ação conjunta de outros agentes, dentre os quais se destacam os próprios editores (SOUSA, 2015), mas não só, uma vez que dada a especificidade deste tipo de material há revisores pedagógicos, de linguagem, de imagens etc. De modo que o produto final apresentado possui uma presença significativa de escolhas realizadas por outros agentes, especialmente considerando-se que em sua maioria tratam-se de livros publicados por grandes conglomerados editoriais.

E por fim, um terceiro elemento que poderia ser considerado nesse processo de aproximação entre as concepções de sociologia presentes nos livros aqui avaliados, destacaríamos o fato de que parte significativa desses autores realizam sua formação acadêmica e intelectual prioritariamente em universidades brasileiras, especialmente aquelas concentradas no eixo Rio-São Paulo, o que poderia apontar para o processo de reprodução de determinadas concepções de ciências sociais que circulam nestes espaços. Infere-se, portanto, certa continui- 
dade entre a sociologia universitária e a sociologia escolar, ainda que possa haver sobressaltos nessa passagem de uma realidade para outra.

No que tange às divergências em termos de concepções de sociologia que encontramos no exame desses livros, que oscilou principalmente na maior ou menor proximidade com uma ideia acerca do papel da sociologia em termos de intervenção na realidade social, destaca-se um elemento bastante heterogêneo na trajetória dos autores que produziram estes livros: a atuação na educação básica, bem como a inserção mais ampla no debate educacional, e mais especificamente sobre o ensino de sociologia.

Ainda que não se possa realizar uma relação direta aqui, é interessante perceber que em muitos casos os autores que produziram tais livros e que não possuem inserção com a educação básica, seja através da atuação direta como docentes, seja através da atuação como pesquisadores na seara educacional e da formação de professores, apresentaram uma visão de sociologia mais própria - a ideia de certa ruptura epistemológica (BOURDIEU, CHAMBOREDON, PASSERON, 2003) -, ao passo que a maior proximidade com a educação básica parece indicar também uma concepção de sociologia mais colada na ideia de transformação social, e em alguns casos de intervenção na realidade imediata. Obviamente que em muitos casos tais ideias aproximam-se da questão da cidadania, que se faz presente de forma relativamente difusa nesses diversos materiais (OLIVEIRA, ENGERROFF, 2016).

0 exame cuidadoso destas concepções nos permite, portanto, compreender como que na educação básica circulam distintas percepções de ciência sociológica, mais que isso, que seus pontos de convergência e divergência se ligam tanto a elementos pró- prios da realidade escolar, como também a outros externos a ela. Como bem nos elucida Vitale (2015, p. 128-129), ao pensar os manuais para o ensino de ciências sociais e econômicas na França, "A recontextualização da sociologia não é somente um problema pedagógico relativo à relação entre ciências sociais e saberes escolares. É, também, o problema da relação entre os conteúdos do ensino e a sociedade." Em que pesem as diferenças entre o caso francês e o brasileiro, acreditamos que tal questão também deva ser encarada por pesquisadores brasileiros, ao pensarem o processo de produção de determinada sociologia escolar divulgada através dos livros didáticos.

Olhar para esta sociologia escolar, em nossa compreensão, é algo relevante para um exame mais amplo da própria sociologia brasileira como um todo, de seus desdobramentos e desafios em período mais recente, especialmente no diálogo que vai para além dos públicos universitários, configurando-se como uma sociologia pública no sentido estrito.

\section{Referências}

ARAÚJO, S. M.; BRIDI, M. A.; MOTIM, B. L. Sociologia. Volume único. Ensino Médio. 1 ed. São Paulo: Scipione, 2013.

BATISTA, A. A. G. Um objeto variável e instável: textos, impressos e livros didáticos. In: ABREU, M. (Org.) Leitura, história e história da leitura. Campinas/São Paulo: Mercado das Letras, 1999. p. 529-576.

BODART, C.; CIGALES, M. P. Ensino de Sociologia no Brasil (1993-2015): um estado da arte na pósgraduação. Revista de Ciências Sociais. Fortaleza, v. 48, n. 2, p. 256-281, jul./dez. 2017.

BOMENY, H. Entrevista. Sociologia da Educação Revista Luso-Brasileira, ano 2, n. 4, dez.2011. 
BOMENY, H.; FREIRE-MEDEIROS, B.; EMERIQUE, R. B.; O'DONNELL, J. G. Tempos modernos, tempos de sociologia: ensino médio. Volume único. 2 ed. São Paulo: Editora do Brasil, 2013.

BOURDIEU, P. Escritos de educação. Maria Alice Nogueira e Afrânio Catani (Orgs.). 16. ed. Petrópolis: Vozes, 2015.

. 0 poder simbólico. 8. ed. Rio de Janeiro: Bertrand Brasil, 2012.

; CHAMBOREDON, J-C.; PASSERON, J-C. 0 ofício do sociólogo. Petrópolis: Vozes, 2004.

BRASIL. Guia de livros didáticos: PNLD 2015. Sociologia. Brasília: Ministério da Educação, Secretaria de Educação Básica, 2014.

CASSIANO, C. C. F. Reconfiguração do mercado editorial brasileiro de livros didáticos no início do século XXI: história das principais editoras e suas práticas comerciais. Em Questão, Porto Alegre, v. 11, n. 2, p. 281-312, jul./dez. 2005.

CHOPPIN, A. História dos livros e das edições didáticas: sobre o estado da arte. Educação e Pesquisa, São Paulo, v. 30, n. 3, p. 549-566, set./dez. 2004.

DESTERRO, F. B. 2016. Sobre livros didáticos de sociologia para o ensino médio. Dissertação de Mestrado apresentada no Programa de Pós Graduação em Educação da UFRJ, 2016.

ENGERROFF, A. M. B. Mapeando a produção sobre o livro didático de sociologia. 2017. $110 \mathrm{f}$. TCC. (Graduação em Ciências Sociais). Universidade Federal de Santa Catarina/UFSC, Florianópolis, 2017.

FERREIRA, V. R.; OLIVEIRA, A. O Ensino de sociologia como um campo (ou subcampo) científico. Acta Scientiarum. Human and Social Sciences (Impresso), v. 37, n. 1, 2015.

HANDFAS, A. As pesquisas sobre o ensino de sociologia na educação básica. IN: SILVA, I. F.; GONÇALVES, D. N. (Orgs.). A sociologia na educação básica. São Paulo: Annablume, 2017, p. 369-288.

; MAÇAIRA, J. P. 0 estado da arte da produção científica sobre o ensino de sociologia na educação básica. BIB. São Paulo, n. 74, $2^{\circ}$ semestre de 2012, p. 43-59. Publicada em julho de 2014.

INEP. Notas estatísticas do Censo Escolar 2016. Disponivel em: <http://download.inep.gov.br/ educacao_basica/censo_escolar/notas_estatisticas/2017/notas_estatisticas_censo_escolar_da_ educacao_basica_2016.pdf>. Acesso em: 10 jun. 2017.

MACHADO, I. J. R.; AMORIM, H.; BARROS, C. R. de. Sociologia hoje. Volume único. Ensino Médio. 1 ed. São Paulo: Ática, 2013.

MAÇAIRA, J. P. 0 ensino de sociologia e ciências sociais no Brasil e na França: recontextualização pedagógica nos livros didáticos. 2017. 342 f. Tese (Doutorado em Sociologia) Instituto de Filosofia e Ciências Sociais da Universidade Federal do Rio de Janeiro/UFRJ, Rio de Janeiro, 2017.

MEUCCI, S. 2000. A institucionalização da sociologia no Brasil: primeiros manuais e cursos. 2000. Dissertação (Mestrado em Sociologia) IFCH, Universidade Estadual de Campinas/UNICAMP, Campinas, 2000.

Notas sobre o pensamento social brasileiro nos livros didáticos de sociologia. Revista Brasileira de Sociologia, v. 2, p. 209-232, 2014.

MUNAKATA, K. Brasil. In: OSSENBACH G.; SOMOZA, M. (Orgs.) Los manuales escolares como fuente para la historia de la educacion em América Latina. Madrid: Universidad Nacional de Educación a Distancia, 2001.

OLIVEIRA, L. F.; COSTA, R. C. R. Sociologia para jovens do século XXI. 3. ed. Rio de Janeiro: Imperial Novo Milênio, 2013.

OLIVEIRA, A; CIGALES, M. P. A pesquisa como princípio pedagógico no ensino de sociologia: uma análise a partir dos livros selecionados no PNLD 2015. Revista de Ciências Sociais. Unisinos. v. 51, n. 3, p. 279-289, 2015.

OLIVEIRA, A.; ENGERROFF, A. M. B. Cidadania e ensino de sociologia nos manuais do professor dos livros didáticos aprovados no PNLD 2015. Estudos de Sociologia, v. 2, n. 22, p. 235-271, 2016. 
PEREIRA, I. P. "Foi neste processo que me tornei um divulgador da sociologia para o Ensino Médio." Entrevista com Nelson Dácio Tomazi. Cadernos da Associação Brasileira de Ensino de Ciências Sociais. v. 1, n. 1, p. 227-238, jan./jun. 2017.

SARANDY, F. M. 2004. A sociologia volta à escola: um estudo dos manuais de sociologia para o ensino médio no Brasil. 2004. Dissertação (Mestrado em Sociologia) - Universidade Federal do Rio de Janeiro/UFRJ, Rio de Janeiro, 2004.

SILVA, A. Vários autores. Sociologia em movimento. 1. ed. São Paulo: Moderna, 2013.

SOUSA, A. P. Gênese social do editor e as novas condições de produção do livro. Caderno CRH, v. 28, n. 73, p. 213-230, 2015.

TOMAZI, N. D. Sociologia para o ensino médio. 3 ed. Volume único São Paulo: Saraiva, 2013.

VITALE, P. A sociologia frente aos riscos dos livros didáticos de ciências econômicas e sociais. Política Et Sociedade, v. 14, n. 31, p. 114-131, 2015. 
RESUMO

0 ensino de sociologia é um tema que paulatinamente vem ganhando espaço na discussão acadêmica das ciências sociais brasileiras, ainda que se mantenha relativamente marginal. Em meio a este debate a questão do livro didático tem se destacado como um relevante objeto de reflexão sociológica. Este artigo busca analisar os diferentes sentidos atribuídos à sociologia nos livros selecionados pelo Programa Nacional do Livro Didático (PNLD 2015), utilizando-se para tanto o exame os livros em si mesmo, como também das trajetórias formativas e de atuação profissional dos autores destas obras.

\section{PALAVRAS-CHAVES}

Ensino de sociologia. Livro didático. Sociologia brasileira. Sociologia escolar.

\section{ABSTRACT}

The Sociology Teaching is a topic that has gradually gained space in the academic discussion of the Brazilian social sciences, although it remains relatively marginal. In the midst of this debate the question of textbooks has been highlighted as a relevant object of sociological reflection. This article seeks to analyze the different meanings attributed to sociology in the books selected by the National Textbook Program (PNLD 2015), using both the books in themselves as well as the formative trajectories and professional performance of the authors of these works.

\section{KEYWORDS}

Sociology Teaching. Textbook. Brazilian sociology. School Sociology. 